\title{
AN ETNOGRAPHIC STUDY OF ELEMENTARY EDUCATION IN THE RURAL AREA OF DOMPU COUNTY, THE PROVINCE OF WEST NUSA TENGGARA
}

\author{
${ }^{1}$ Nurrahmah; ${ }^{2}$ Zamroni; ${ }^{3}$ Sumarno \\ ${ }^{1}$ Mataram State Islamic Institute; ${ }^{2,3}$ Yogyakarta State University \\ 1rahmah03@yahoo.com; 2zamroni1947@gmail.com; ${ }^{3}$ sumarno_unj@yahoo.co.uk
}

\begin{abstract}
The study aims to describe: (1) public service for elementary education in rural areas; (2) the meaning of education and the implementation of elementary education in the people of rural areas; and (3) the life and meaning of poverty for people of rural areas. The study was etnographic research. The subjects were the providers and users of educational service. The research concludes that: (1) educational service in rural areas has not been coordinated and integrated both vertically and horizontally, so that the service elements have not been maximum in providing educational service; (2) the implementation of education is influenced by the surrounding environments (policy, community, and nature) so that its condition or the problems emerging in the lower level is a reflection of that in the upper level. People in rural areas regard education as a symbol of profession and self-actualization within the children's selves in order that the children would show respect to their parents, would not destroy the nature, have noble characteristics and be smart persons for their own sake in the future; (3) physically people in rural areas might be described as a community that lacks facilities including transportation, highway systems, water, electricity, and market for trading the harvest. On the other hand, mentally, people in rural areas might be described as a community that is fond of having aids, enjoys the final products, is lazy and dependent on the nature. People in rural areas regard their poverty based on physical indicators (the possession of luxurious goods, rice fields, livestock, income, and housings) and non-physical indicators (the dependency on the nature and absence of education).
\end{abstract}

Keywords: etnography, elementary education, rural areas

How to cite item:

Nurrahmah, N., Zamroni, Z., \& Sumarno, S. (2016). An etnographic study of elementary education in the rural area of Dompu county, the province of West Nusa Tenggara. Research and Evaluation in Education, 2(1), 79-91.

doi:http://dx.doi.org/10.21831/reid.v2i1.8270 


\section{Introduction}

After being an independent state for more than 60 years, Indonesia still encounters insufficient educational service for elementary education and high education. Sudarminta (2000, pp.9-13) mentions that there are three educational problems which are encountered by the state in the third millenium: Low educational quality, insufficient learning systems in schools, and the widely-spread moral crisis in society. Slamet (2008, p.1) states that the educational drawbacks owned by the Republic of Indonesia, in comparison to other ASEAN countries, are related to the following aspects: (1) the amount of educational participation, (2) the period of 9-year compulsory education, (3) educational quality, (4) the average learning period (in general only 7 years of education), and (5) the poor efforts in improving education system. As a result, educational discrepancy has become very wide.

The World Bank (2012) reports that institutional weakness becomes the potential drawback for educational improvement in Indonesia, especially in the case of elementary education. In relation to the drawback, the World Bank also provides recommendations for improving education in Indonesia. The recommendations finally encourage the birth of decentralization and regional autonomy in almost all sectors including education. From political perspective, many regions would like to become independent. However, from the natural resource and facility perspective, the dream of becoming independent areas seems impossible to realize.

Similarly, Dompu County, as a region under the Province of West Nusa Tenggara (or NTB for short), also has suffered from similar problems since the county implemented the autonomy system in 1999. Compared to the other counties in NTB, Dompu County is classified as one of the poorest autonomous areas. A quote from the study performed by Smeru Research Institute (2005) strengthens the description of the county as follows:

Using the 2000 administrative arrangement as a reference, the FGD participants ranked Mataram as the highest, since the people in this capital city of NTB are considered as the wealthiest compared to the people in other districts. Dompu is placed at the lowest rank because the area of this district is very large and the population density is low. The condition of the people in Dompu was considered to be lacking in all aspect, including bealth condition, education level, income and infrastructure. Bima, located in the eastern part of Sumbawa Island, was ranked second because this region is the gateway to and from East Nusa Tenggara, as well as the center for development in the eastern part of NTB. Many people from Bima have also become successful emigrants to other Island.

The bottomline is that the results of the research place Dompu County into the lowest rank in comparison to the other counties such as Mataram and Bima. From the aspect of health condition, education, income and infrastructure, Dompu County still needs more improvement.

Tukiran (1993, p.15) states that in order to determine whether a region is poor or not, the government might refer to the indicators that reflect the poverty, namely potentials, facilities, settlements and residents' condition that the related region has. Furthermore, Sumodiningrat (2000, p.56) argues that a poor society in general is marked by their inability or their powerlessness to, for example, meet the fundamental needs such as food, nutrition, clothing, housing, education and also health.

Compared to the Regional Gross Domestic Product (RGDP) of other counties that have been well-structured, the RGDP that Dompu County has might be classified as very small - only Rp 1,984 billion, whereas the percentage of poor people in the county is $19.90 \%$. Based on the data in Nusa Tenggara Barat dalam angka (Central Bureau of Statistics of Nusa Tenggara Barat Province, 2011), the percentage of Dompu County residents in terms of illiteracy from 10 years old and above has been $11.33 \%$. Of the five counties capital in Sumbawa Island, Dompu County is in the second place after Bima County in terms of the number of illiterate people.

Many programs have been initiated and implemented by the regional government, both in educational and in economic sectors. In the economic sector, the regional govern- 
ment has initiated a program for improving the maintenance of cows, corn and seaweeds called Pijar (sapi (cow), jagung (corn) and rumput laut (seaweed)) with an expectation to decrease the number of poor people for about $10 \%$ each year. In the education sector, the regional government has implemented free education in the elementary level and even in the higher level. The construction of learning facilities such as the school buildings and the provision of educational aids has been performed as well. However, in practice, the government has not attained satisfying results. According to the Team of Educational Advocacy formed by the government of Dompu County, there are two matters that mainly inhibit the implementation of good educational service, i.e the low level of students' participation and the low level of teachers' attendance, especially those in the remote areas. Although education has been free of charges, the children keep leaving their school during their school period. The two main reasons why the children leave their school are to help their parents earning the living for the family (especially whose parents are fishermen) and to earn their own allowance (especially in the case of peer influence). In relation to the problem, ILO (International Labour Office, 2003 , p.22) provides the statement as follows:

The education and preparation for working life of the current generation of children are of key importance to the drive to reduce and eradicate extreme poverty. Children from families living on poverty incomes often start work at the age when their better-off counterparts are beginning to read.

Education for children is actually the key factor for overcoming poverty. However, the children from families with lower economic background has started to work at the age when they should start reading.

Sachs, quoted by Suharko (2007, p.4), states that a strategy for overcoming poverty will be to break down the 'hereditary poverty chain' before eliminating the poverty problems. Although the poor have the intention to solve their problems, they will not be able to do that with their own resources. The main point is that the poor should be assisted in solving their poverty problems.
Furthermore, Surakhmat (2009, pp.1718) argues that from the perspective of education, the answer to poverty elimination is in the efforts to improve the society's spirit, power and ability in order to help themselves. In this regard, education has a very important role in overcoming the negative effect caused by the cycle of drawbacks. Zamroni (2010, p.185) also supports that the role of education in poverty elimination is very decisive. The countries that have succeeded in eliminating poverty are the ones that have been able to provide education for all of their citizens.

Based on the existing conditions and opinions that have been reviewed, it is clear that poverty and education are interrelated. Poverty makes people or a group of people unable to access sufficient education. On the contrary, education might not be accessed by people or a group of people if they are poor naturally, culturally and even structurally. Specific to the research site, although the educational service has been provided freely and the number of school buildings is increasing, the children keep leaving the schools because of the multiple forms of poverty that they suffer from.

The question, now, would be: What is the importance of constructing more and more school buildings from one year to year if the children or students keep leaving school? Then, how will educational process be implemented if the teachers do not support the implementation of education? Another question that might be proposed is: Why does Dompu County, which is one of the sub-districts which becomes a tourism destination, the producer of seaweeds and the mining area, suffer from educational drawback? Last but not least, why does the increasing number of educational aids not improve the students' awareness and participation in the educational process?

In general, the underlying question might be as follows: Why is it hard to cut down the poverty chain? Experts from the World Bank provide a new paradigm that the increasingly multidimensional poverty should not be seen from the outer layer. Narayan, Chambers, Shah, and Petesch, (2000, p.1), specialists of social development from the 
poverty-handling department of World Bank, state that the poor are the one who understands himself or herself. The results of a study by Thuy (2012, p.196) also support the statement and these results imply that the different community members have different definition and interpretation of poverty. They provide their definition based on the condition of their poverty.

Therefore, this etnographic study was performed in order to understand the meaning of education and poverty from the perspective of the society which is included the cycle of poverty. The reason is that the educational drawback has been very complex and related to social, cultural and economic problems. As a result, there should be a research method that might have an in-depth review on the relationship among the interrelated problems based on the facts in the society in which the education has been implemented. The matters related to the perspective and daily life might be easier to understand by means of an etnographic-qualitative approach because the approach is closely related to the values of belief, paradigm, life and behaviors and these values might not be investigated quantitatively.

The objective of the study is to describe elementary education service and its implementation in the rural areas and to describe the meaning of life and the meaning of education and poverty for the community in rural areas.

\section{Method}

Two etnographic approaches were implemented, namely realistic ethnography and institutional ethnography. The study lasted for four months from September 2012 until December 2012. It was performed in two subdistricts that were classified as poor and remote areas in Dompu County, the province of West Nusa Tenggara. The two subdistricts were Hu'u and Pekat. Observations to 22 elementary schools and junior high schools or the equivalent educational institutions were conducted. The subjects were educational service providers and educational service users. The data were collected by means of participatory observation, interview and docu- mentation. The data validity was attained by the following multiple manners: deviating evidence investigation, triangulation, participatory methods, comparison, quasi-statistics and implementation of detailed, complete and various data. The data were analyzed sequentially according to the stages in an etnographic study and the sequence were as follows: Domain analysis, taxonomy analysis, componential analysis and cultural-theme analysis.

\section{Findings and Discussion}

Although education and poverty might be a cause and effect altogether at the same time, the research was connducted based on the assumption that education is the key factor to overcome poverty. Based on the assumption, it is obvious that if education were improved, then poverty would be decreased and vice versa.

Elementary Educational Service in Rural Areas

The educational service in the study is categorized into three aspects: Teachers, curriculum, and facilities. The focus classification was performed based on the matters directly involved in education.

Quantitatively, the number of the teachers in rural areas does not decrease and this is apparent from the ratio of teacher to student. The ratio of teacher to student in rural areas is smaller than that of the national one. The problem is on the teacher distribution and quality. The teachers in rural and remote areas are dominated by the part-time ones. As a result, the schools have only two or three fulltime teachers. Most of the part-time teachers are appointed by means of recruitment process held directly by the schools. Consequently, the payment of the part-time teachers becomes the schools' responsibility according to the financial level. On the other hand, although there have been several part-time teachers who possess the right to have incentives from the regional government, the amount of the incentive is relatively low.

Then, the attendance level of the teachers in rural areas may be classified as very low and this matter is reflected from the inappro- 
priate learning process. A teacher may be absent for a day and even for a week consecutively. There are various reasons for the low attendance level, such as: The teachers do not come from the local area or do not live around the school area; the learning facilities in the remote areas do not support the teachers' settlement; and the malfunction of educational offices in the county. Another reason is the low supervision performed by the educational supervisors and the low leadership quality performed by the principals.

Furthermore, another important matter was the curriculum which is implemented by the schools in the educational process. During the research period, the schools that become the subjects of the study implemented schoolbased curriculum (Kurikulum Tingkat Satuan Pendidikan or KTSP) and there was a training for the vice principals to strengthen the curriculum implementation. The Head of Curriculum Department in the Regional Office of Youth and Sport states that one of the problems in the implementation of the curriculum is the schools' and the teachers' capability of elaborating the curriculum into smaller components such as the basic competence, the competence standard, and the passing grade. The results of a study conducted in two different sub-districts show that the local subjects might be made flexible in accordance with the community's demands and problems in each sub-district. For example, in the SubDistrict of Hu'u that becomes one of the tourism objects, the local subject is the health of reproduction system. On the other hand, in the Sub-District of Pekat that has been dominated by Sasak tribe with high number of premature marriages, the local subject then should be the problems of having premature marriages. However, the development of local subjects is inhibited by the low socialization of the Regional Office of Youth and Sport, the distant communication channel among the sub-districts, and the lack of information regarding what aspects should be loaded in these local subjects. Facilities are also important in educational process. The schools in distant areas might be considered as being established based on the community movement. This aspect is apparent from the exist- ence of schools in each village. In general, the ratio between the number of schools and students is acceptable. Similarly, the ratio between the class and the student number in general is acceptable as well. Unfortunately, the buildings, especially the classrooms, in these schools are only built from bamboos and palm leaves. In addition, these classrooms in most cases should be split into two rooms due to the space inavailability.

Another aspect that should be given attention to is that almost all of the schools within the rural areas are the facilities as follows: Toilets, hygienic water, libraries and electricity. Furthermore, the principal's office, that is usually combined with the teachers' office, the library and the visual aids, should be given attention. Because of this, the students do not have freedom in reading the books or in using the visual aids. The Regional Office of Youth and Sport states that the schools are built according to the community movement for the sake of adaptation between the community and the environment, especially for the farmers whose fields are separated from one another. However, the construction is built from one phase to another. Moreover, the regional government has limited ability in affording the teachers' office if the office should be constructed separately from the schools and the principal's office.

The Implementation of Elementary Education in Rural Areas

The implementation of educational process is focused on the students, learning and environments that affect the educational process itself: Policy, community and nature. The students in rural and remote areas might be described physically and mentally. Physically, these students, especially those in rural areas, have red hair and dark complexion due to the sun heat. In addition, they also tend to wear various shirts or dresses and sandals to school. Mentally, these students have low attendance level in school for several reasons. First, the teachers' attendance level in their schools is low. Second, they have to go to work with their parents. Third, they have to take care of their relatives. Fourth, they have festival days to celebrate. Fifth, they have to 
deal with the unfriendly weather. Because of those reasons, the teachers in rural areas have extra task, namely, to find and take these students back to schools because they rarely attend the classes in the schools.

From the aspect of achievement, these students, especially those in the rural areas, are generally low. Although the data found in the Regional Office of Youth and Sport show that the results of their national examination are ideal, in practice, based on the results of the study, these students are very low especially in fundamental abilities such as reading, writing, calculating, and understanding general knowledge about the Republic of Indonesia. These students also had not understood their timetable as well. It seems that there might be an association between the habits in family and the students' low achievement. A research performed outside the school period finds that the parents do not supervise and guide the children in their learning process. Similarly, the principals and teachers have also stated that although the schools have provided timetable, it will not work without parental supervision.

Furthermore, most of the schools in rural and remote areas applied the teaching process uniquely. Most of the teaching processes were not implemented according to the lesson plan because the teachers grouped the students from different classes. This had been done in order to cope with the teachers' absence, the lack of classrooms, and the low students' attendance. When these students were grouped into one class, the teaching process was conducted in one of the following manners: Either the blackboard would be divided into two or three parts, or the students would be given general assignments.

The other aspect that supports the implementation of teaching processes is environment. In this regard, environment refers to the community, the policy and the nature. Environment might provide both positive and negative effects to the educational process.

Community is an environment in which the students spend most of their time. Parents and society are responsible for supporting the educational process that the students have by, for example, supervising the educational pro- cess implemented in the society. The supervision also covers the students' activities in society. However, in practice, the students' activities, especially learning activities, are not supervised well within the community as having been the case in the Sub-District of Hu'u and Pekat that have been dominated by Bima and Dompu tribes. In these cases, students are found to perform activities in contrary to their learning process and, at the same time, parents also do not provide good examples for their children. For instance, the parents invite these children to be involved in musical events from evening until dawn and they are also asked to drink liquors. Furthermore, these children also do not respect their peers who have been praying in the mosque during the musical event. On the contrary, in several communities of the remote areas, especially in the transmigration area which is dominated by Sasak tribe (Lombok), the learning process in the society has been implemented well. Children in these areas have religious activities that are directed to educational processes. Unfortunately, this tribe has a tradition named merari kocet or having premature marriage. The tradition has become one of the drawbacks for the teaching process in Sasak tribe.

Another case that happens in most of remote and rural societies is the use of educational aid fund for inappropriate matters. Furthermore, these societies employed card for the educational aid, namely the program of expected family (Program Keluarga Harapan or $\mathrm{PKH}$ ) as a guarantee for getting loans.

The government's policy in the domain of education is aimed at improving education itself. The improvement of education might be pursued through the following efforts: Free education, scholarship grant, incentive grant for the teachers, and the construction of learning facilities. However, such policies in some cases do not meet the expectations. The process of recruiting the principals, teachers and educational supervisors does not meet the demands and regulations. The process does not calculate other aspects that might affect further educational processes. On the other hand, the principals in some other cases recruit temporary teachers and the recruitement is out of their jurisdiction; as a result, there 
has been abundance in terms of temporary teachers within certain schools and, therefore, there might be inappropriate incentive/grant to these temporary teachers. Recruiting principals and educational supervisors without calculating the demands might change the teacher composition, especially for the permanent or full-time teachers, specifically for those who come from the same educational background.

The unclear jurisdiction between the regional office of education and the subdistrict office of education also becomes another aspect that should be given attention. The sub-district officers of education think that they do not have clear jurisdiction. The case is apparent from the ill-function subdistrict office of education. The principals, teachers, and educational supervisors have direct coordination to the regional office of education without having been connected to the sub-district office of education first. Eventually, the learning process in the subdistrict office of education has been left behind compared to that of the regional office of education.

From the aspect of environment, geographical condition also affects the educational processes, especially in the second research site: Sub-District of Pekat. Pekat sub-district consists of separated mountainous areas. It lacks transportation facilities and has an unreliable highway system. It also has high rainfalls. As a result, the students have low attendance level and change timetables because of the weather condition.

\section{The Meaning of Education for the Poor}

The meaning of education for poor people in the southern tip of Indonesia is to improve the quality of human resources who will cultivate natural resources. According to these people, human resources are the sources for all natural resources. The reason is that education will form the characteristics of human resources who will cultivate natural resources, and education will eventually change their traditions or behaviors. Therefore, by means of education, human characteristics might be improved.
Similarly, one of the principals who becomes the study subjects gave the following statement:

....di sini ada tambang yang masuk...saya berikan arahan...pandangan pada siswa itu... ini tambang ini anak-anak untuk kamu semua, bukan untuk orang lain. Kalau kamu memang tidak sekolah, tidak mungkin kamu masuk di tambang itu....harus orang yang berpendidikan...harus orang yang berijazah...

(We have a mine in this area. I tell my students that the mine belongs to them. So, if they do not go to school then they will not be able to work in the mine because only educated people are able to work in the mine.)

This matter is associated to the potential natural resources that the Sub-district of Hu'u has and the cultivation of the natural resources by external people because of the incapable human resources. Furthermore, the principal also stated:

....tidak ada lagi yang tidak sadar sekolah sekarang, harus sekolah semua...kalau memang tidak sekolah kan rugi...nanti menyesal...tidak ada duluan...pasti belakangan...pasti menyesal nggomi doho watisi banumu...tio kaimu maa batu polisi...maa batu hanu...musti punya ijazah...batu ketua RT saja harus punya ijazah sekarang... siapa tau nggomi doho ake pede...ndadi presiden kombi...ndadi menteri kombi pede.

Now, all of the people in this subdistrict have been aware of going to school. They have also been aware that if they do not go to school then they will feel sorry for themselves. And feeling sorry always comes late. Even being a chief of community should have educational backgrounds. We are never able to predict the future. If you have good educational background, there might be a possibility that you become a minister or even a president in the future.)

The principal provided the meaning of education for his students in the future. He emphasized that all of the students should go to school or otherwise they would be left behind. Furthermore, he stated that even if 
they wanted to become a chief of community or a policeman they should have good educational background. By having good educational background, they might also be a minister or even a president.

Furthermore, the principal of Public Elementary School of 13 Hu'u viewed that education or knowledge that his students have might change their destiny in the future. This matter has been proven before; although his stu-dents were only able to speak English and play ski, they had been successful in their life. He provided the statement as follows:

Punya ilmu...orang anak-anak yang sudab punya ilmu itu sudah kaya raya..hasil didikan saya...maksud saya..dia sudah bisa berbahasa inggris, dia mendapat uang dari turis-turis manca negara...ada yang sudah kaya betul itu...baru usia belasan tabun.

(My students who have had enough knowledge now are successful and rich. I mean that they have been able to speak English and they earn money from guiding foreign tourists. Even one of my students has become very rich although he is still very young.)

The principal elaborated further that his students who had been able to speak English and play ski had been made as foster children by foreign tourists. They had even been given some fund for starting their business. These foreign tourists disliked the children who had poor educational background.

Then, the Chief of School Committee in the Public Elementary School of $08 \mathrm{Hu}$ 'u from the Sub-district of Hu'u stated that the students should have education not for being the civil servants but for making them aware of themselves and showing respect to their parents. Then, what type of education should the students have? At least, the type of education that the students should have might be preserving the nature such as not operating the instrument that might endanger sea life.

Within the discussions with the students of public junior high school, it is found that these students have high expectation on the education that they attempt. These students said that they want to go to school because they want to be smart so they would be able to get a decent job. By getting a job, they might save money so they would be rich. Although they do not have teachers, they might learn from any book by themselves. From these discussions, two matters in the paradigm, namely, the meaning of education and their future expectation on education, are found. For these students, going to school means to be smart in order to be able to have occupation so that they might be rich people.

For the students in elementary school, going to school means to be teachers, midwives, doctors, policemen and even farmers. A similar statement has also been provided by the students from an elementary school in a remote area. They said that they go to school in order to be teachers, midwives and doctors although they are poor and they have limited access to electricity in their daily life.

On the other hand, one of the students' parents who works as a seaweed farmer stated that going to school would mean nothing if they could not earn their living. He gave his statement as follows:

Sakola kapa'i ademu labo daa ngaha katantu bata pa wa'uni made.

(Going to school without being able to earn the living would be in vain.)

This parent chooses to bring his children to go working although they have to leave their school because they would be dead if they could not earn their living.

However, a different statement was provided by a mother, who stated that by going to school, her child becomes slightly smarter and finally he can afford an occupation. She gave her statement as follows:

De watini ne'e jaa kau loa ana sato'i...ne'e jaa karawi sato'i...ndede pa.

(I want my child to be smarter so that he might afford an occupation. That is the reason why I send him to school.)

Furthermore, the Principal of $02 \mathrm{Hu}$ 'u Public Junior High School of explained the meaning of education in the following detail:

Ya kalau menurut saya itu...pada titik terakbir itu bagaimana anak itu berketerampilan yang bagus...kemudian itu juga berdasarkan 
agama itu bagaimana anak itu berakblak yang mulia itu...menjadi orang yang baik...yang pintar dan untuk masa yang akan datang buat mereka itu..kalau menurut saya...makanya di sekolah kita ini sering dilakukan imtaq setiap hari Jum'at misalnya apa yang kita lakukan itu baca yasinan... kemudian ada istilabnya lagi senandung Al-Qur'an diberikan pada anakanak itu....sehingga nanti anak itu ada perubahan sedikit demi sedikit...karena kita mengingat bahwa akbir-akbir ini banyak anakanak yang tawuran...kemudian hal-hal yang lain yang kita lakukan seperti tadi...anakanak diajak untuk melakukan kegiatan ekstrakurikuler itu tadi untuk seperti lintas alam... sehingga mereka itu tidak ingat lagi halbal yang tidak hanu.

(In my opinion, at the very last point, educational process is about to have good skills. From the perspective of religion, educational process is about to have noble characters, to be good people and to be smart people for the sake of their own future. Therefore, in our school, every Friday we have imtaq (a program of spiritual guidance), yasinan (reading Surab Yasin together) and AlQur'an recital. The students start to improve slightly and this is very good regarding the case of students' fight that has happened recently. Then, we also invite our students to be involved in extracurricular activities, such as, camping so that they will forget improper and unnecesssary things.)

The principal's explanation regarding the meaning of education is related to the recent development of the children in the Sub-district of Hu'u who are involved in the problems of drug abuse and free sex. The existence of tourism object and mine provides negative effect to the students' behaviors and association.

\section{The Description of Life in Rural Areas}

Physically, people living in rural areas might be described as those who lack lifesupporting facilities such as water spring, markets (where to buy the daily needs and to sell the crops and cattle), and communication channel. In remote areas, especially in rural and mountaineous ones, those facilities are far below the required standards; the highway is insufficient, the water spring is located far from the settlement, the electricity does not work properly, and the market is located far away from the settlement as well. As a result, these people, especially the farmers, are unable to sell the crops and cattle, and although they might be able to sell them, the price will not exceed the production cost and the sale price. This situation also causes high additional cost in affording the seed and fertilizer.

Most of the people who live in remote and rural areas work as farmers and fishermen. When they have to face the problems such as harvest failure and unfriendly weather, these people choose to sell or put the rice field into mortgage. In the first research site, namely the Sub-District of Hu'u, the farmers sold their rice fields to new owners; however, when the harvest period came, they would collect the remainder of the crops in the rice fields that used to belong to the people.

Based on the afore-mentioned explanation, the reason why the life of the people has not changed is more of internal factors. No matter how great the blessing that they have and the income that they have earned, the life of these people would not have changed if they did not use both benefits for the productive matters. In addition, the case became worse if the people were lazy when they actually should go to work, whereas they could change their life if they go working.

Brand, as having been quoted by Thut and Adams (2005, p.520), states that the poverty of a country might be caused by: (1) low productivity land, (2) the lack of capital, (3) low educational level, and (4) low leadership in initiating economic development. Furthermore, he explains that the elements of underdeveloped economy might be associated with causal relationship that creates an evil cycle, and the evil cycle depicts how the underdeveloped countries nurture such association (Thut \& Adams, 2005, pp.520-521). One of such evil cycle, as having been observed by the economists, is presented in Figure 1. 


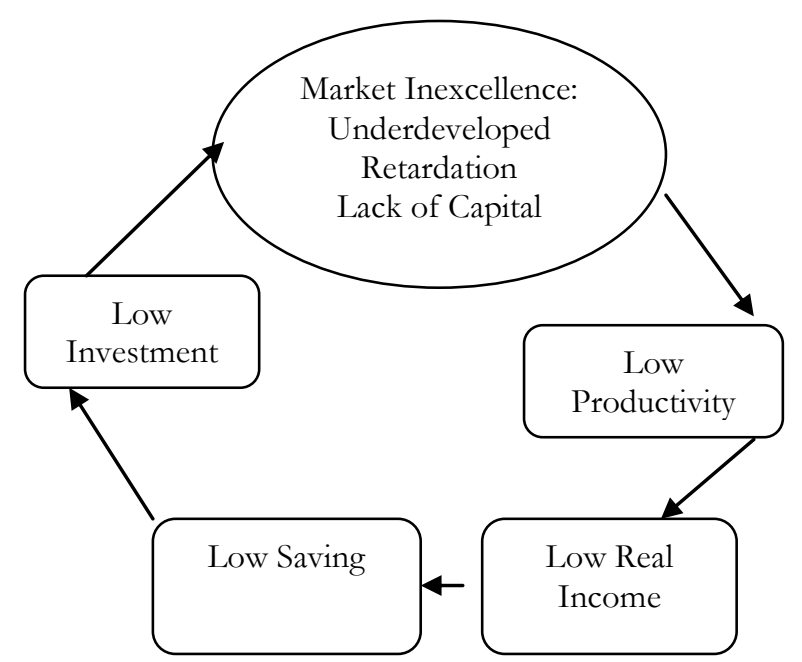

Figure 1 . The evil cycle of poverty

Thereby, a group of elements such as market inexcellency, low quality labors and alike might cause low productivity and eventually the lack of capital. The lack of capital is a situation inhibiting economic development and, in higher level, inhibits social and educational development.

Based on Figure 1, it is found that low income will cause low saving. In practice, although most people in the research sites belong to the area of high income, it does not imply that they have increasing saving or economic life. They tend to spend their income on unproductive matters instead of productive ones such as having investment or pursuing the business capital. For instance, seaweed farmers and woodsellers earn Rp 2,000,000.00 a week; but they tend to waste their money by hiring bands and buying liquors.

Koentjaraningrat (1987, p.4) explains that the cultural value that most Indonesian should have is 'future-oriented'. Such cultural value will encourage people to overview and plan their future very carefully, therefore, they should be wise with their income. All of us are aware that the widely-spread trait of being economical would be necessary for a nation to accumulate as much capital as possible.

Furthermore, farmers in the second research site, the Sub-district of Pekat, have a habit of selling their rice fields for affording marriage and working abroad because they do not have sufficient income. In the case of working abroad, they will use the income they have earned for repurchasing their rice field.
The regional policy of turning Dompu County into the centre of corn plantation does not help the farmers to improve their life quality. Although the regional government has encouraged the program, the farmers are still inhibited by the expensive price and the scarcity of seeds and fertilizers. The case becomes worse when the farmers do not find any market for selling their crops after the harvest period, whereas the crops and other agricultural products are very fragile. As a result, these farmers do not have any option other than selling the crops and the agricultural products in a low price. Such problems actually give contribution to the poverty faced by the people and become their reasons for selling their rice fields or working abroad.

The Meaning of Poverty for People in the Poor Areas

People in the poor areas have different perspectives of interpreting poverty. The perspectives depend on their view and position in observing poverty.

When the students were asked to mention what someone has if he or she is regarded as a rich person, they mentioned one by one that it is household utensils that represent the status of being rich. The household utensils that they mention might be found in one of the quotes from the interview with the students of junior high schools. According to these students, the people who are categorized as being rich are the ones who have the items such as refrigerator, television unit, washing machine, rice cooker (some of the local people call it 'kuskes'), and parabole antenna. In another occasion, when these students were asked about the meaning of rich people, most of them answered that rich people are the ones who are able to afford schooling. However, other students disagreed with them and this group of students proposed that the people who are able to afford schooling would eventually find an occupation and finally would be rich. The question was intendedly asked in order to find the definition of being poor from other point of view. In addition, using such a question would make it easy for the students to propose their statement. Based on the discussions, it is con- 
cluded that poor people are those who have the situation in contrary to the definition that these students have mentioned.

When the criteria of being rich and poor are asked to a group of parents, the following responses are provided:

\section{Dou ma miskin re dou ma darere}

(Poor people are the ones who have nothing.)

Kade'e mbere langi...

(Wait for the heavy rain falling from the sky.)

Kade'e mbere langi...ngena banupa di ru'u oma

(Wait for the heavy rain falling from the sky, only for the rice fields.)

Edepa di pandana...tiwara tolo...

Just wait for the heavy rain falling from the sky, because we do not have any rice field.)

Di doropa...rahanu edepa...kanggibi sakali samba'a...nawara walisi ura nawara diweha... tisi wara ura indo wara di weha

(Living only in the hills and not having any rice field. If we have heavy rain, it means we might have something to harvest. If we do not, it means we might not have anything to harvest.)

From the discussion, it is found that the group of parents views poor people as the ones who are only waiting for the heavy rain to fall from the sky upon their rice field, and the ones who do not have fertile rice field. According to them, poor people had harvest period only once in a year and the harvest depends on the rain. If they have heavy rain, then they might have their harvest and vice versa. On the other hand, another group of parents views the rich people as those who have rice fields, cows and horses. Cows and horses are beneficial cattle for local people because they can benefit their strength for cultivating the land, for selling the cattle and for transporting their items.

These parents' view implies dependency on the condition of the nature. The view is in accordance with the results of a research by
Kutanegara, Mustar, and Purwatiningsih (2007, p.170) which conclude that the condition of villages in the hilly areas and the poor transportation causes the people to be dependent in the existing situation. Their being surrendered to the existing conditions is mostly found in Javanese people, including those in the Special Province of Yogyakarta and of Central Java. In relation to the statement, the results of the study show that the people living outside Java Island also have a similar trait. Narayan, Chambers, Shah, and Petesch (2000, p.22) also state that although the experience of poverty might be different for different groups of people, there might be peculiar similiarities that the different groups of people shared.

In addition, when a principal was interviewed, he implied that the indicators of being poor are viewed from the aspect of income, field possession, and cattle possession (especially the cows). In relation to the statement, a mother from Sorinomo, the Sub-district of Pekat, views poverty by comparing her condition to that of the people around her who are granted the $P K H$ aid. She said that the people who are granted the $P K H$ aid might not be classified as poor people because they have better condition than her; they have better houses, more cattle and more fields.

Going back to the definition of being poor, the following question was asked to another principal from one of the public elementary schools in the most eastern tip of Indonesia: 'Might being lazy and uneducated be regarded as being poor?' The principal answered, 'It means total degradation because these people are lazy and uneducated; as a result, they finally sell every single item of their belongings whereas they used to be rich.' Such phenomena occur frequently in local people. The local people sell their rice field to new owners and when the harvest period comes, these people collect the remainders from those rice fields.

Based on the definitions of being poor that has been elaborated, it is found that the respondents or the informants regard poverty by viewing the surrounding aspects and the experience; in addition, they also compare the past and recent situations as well as the exist- 
ing and external condition within the areas where they live.

\section{Conclusions and Suggestions}

The educational institutions in Dompu County has not been well integrated and well coordinated both vertically and horizontally in terms of providing educational service. As a result, the elements or indicators of educational service such as teachers, curriculum, and learning facilities have not been maximum in terms of providing educational service for the rural areas. The teaching process does not meet the expectation especially in the rural and remote areas.

The implementation of education in the lower level reflects that of the higher level, so when the higher level education face certain problems, then the lower level education will also have problems. The reason is that the implementation of education is affected by the surrounding environment, namely the policy, community, and nature.

The level of students' participation and achievement in the educational process is affected by the cultural capital they inherit, the experiences they have, the community where they come from, and the culture they learn during the teaching process in the school. In other words, the students' participation and achievement are the reflection of cultural process that they get from the school and from the community. If the culture in the teaching process and in the community changes, then the teaching process and output that the students get will also change. On the other hand, if the teaching process changes, then the culture that the students and the community have will also change. The process of cultural change might occur negatively and positively to both the community and the teaching process itself.

Such a process of cultural change that has been reflected in the students and community members is also reflected in their view of education. Based on the experience and natural condition that surround these people, the community regards education as follows. First, they regard education as a means of achieving their dreams through the possession of profession, the knowledge in certain occu- pations, and knowledge for exploiting the natural resources. Second, they regard education as the efforts to encourage their children to be respectful toward the parents and nature. Education is regarded as a process of mastering certain skills and having religious basis for pursuing noble characters. The students should be smart not only for their own sake, but also for other people's sake. However, there is a different meaning of education: Education would mean nothing if it is not able to earn a living. The meaning is given by a seaweed farmer who chooses to bring his children to the coasts rather than to school.

Physically, the people in the research sites can be described as the ones who lack sufficient facilities such as transportation, highway, water, electricity and market; market is very important because in the market, these people, especially the farmers, might purchase their daily need and sell their crops or their cattle. Mentally, the people in the research sites can be described as the ones who suffer from poverty; they are fond of having aids, enjoying the final products and depending on the nature.

Based on the situation that they have and the natural condition that surrounds them, the people in the rural areas provide the meaning of poverty based on the physical and non-physical indicators. From the physical indicators, poverty is classified by referring to the indicators that show the presence (the possession) or the absence of luxurious items, land, cattle, income and houses. Then, from the non-physical indicators, poverty is classified by referring to the dependency on nature, namely by 'expecting the heavy rain to fall from the sky.' If the rain falls from the sky, then they will have something to harvest and vice versa. Another opinion implies that not having sufficient educational background might be regarded as being poor because it will encourage people to sell their rice field and they would finally be poor whereas they used to be rich.

From the research findings, in order to improve the educational service, the following steps are suggested. The provider of educational service should delegate the authorities from the level of regional government to that 
of sub-district government with a clear jurisdiction in order to shorten the chain of administration so that the service and the implementation of education might operate well. Then, the curriculum applied in the rural and remote areas should be adapted to the situation of local people based on the geographical condition, the potential natural resources, and the problems that inhibit to the implementation of education. The future researchers of educational etnography are suggested that perform a similar study with a bigger number of sample in order to have wider implementation of the results.

\section{References}

Central Bureau of Statistics of Nusa Tenggara Barat Province. (2011). Nusa Tenggara Barat dalam angka [Nusa Tenggara Barat (NTB) in figures]. Mataram: Central Bureau of Statistics of Nusa Tenggara Barat Province in cooperation with Regional Development Planning Board of NTB Province.

International Labour Office. (2003). Working out of poverty. Geneva: International Labour Office.

Koentjaraningrat. (1987). Kebudayaan dan mentalitas pembangunan [Culture and development mentality]. Jakarta: PT. Gramedia.

Kutanegara, M., Mustar, E., \& Purwatiningsih, S. (2007). Mendorong program kemiskinan dan raskin berbasis lokal [Encouraging local-based poverty and rice for poor society programs]. Populasi, $18,167-185$.

Narayan, D., Chambers, R., Shah, M.K., \& Petesch, P. (2000). Poverty is powerlessness and voicelessness. Finance \& Development, 37(4), p.18.

Slamet. (2008). Desentralisasi pendidikan di Indonesia [Educational decentralization in Indonesia]. Jakarta: Departemen Pendidikan Nasional.

Smeru Research Institute. (2005). Developing a poverty map in Indonesia: A tool for better targeting in poverty reduction and social protection programs. Retrieved from www.smeru.or.id/.../povertymapping4/

Sudarminta, J. (2000). Tantangan dan permasalahan pendidikan di Indonesia memasuki milenium ketiga [Educational challenge and problems in Indonesia entering the third millennium]. In A. Atmadi \& Y. Setiyaningsih. (Eds.), Transformasi pendidikan memasuki milenium ketiga [Educational transformation entering the third millennium] (pp.315). Yogyakarta: Kanisius.

Suharko. (2007). The roles of NGOs in rural poverty reduction: The case of Indonesia and India. Nagoya: Nagoya University.

Surakhmat, W. (2009). Pendidikan nasional: Strategi dan tragedi [National education: Strategy and tragedy]. Jakarta: PT Kompas Media Nusantara.

Thut, I.N. \& Adams, D. (2005). Pola-pola pendidikan dalam masyarakat kontemporer [Educational patterns in contemporary society]. (SPA Teamwork, Trans.). New York, NY: McGraw-Hill Book.

Thuy, T.N. (2012). Poverty reduction strategies in an ethnic minority community: Multiple definitions of poverty among Khmer villagers in the Mekong delta, Vietnam. Asian Social Science, 6, 196-208. doi:http://dx.doi.org/10.5539/ass.v8n6 p196

Tukiran. (1993). Penentuan desa miskin [Determining poor villages]. Populasi, 14(1), 13-23.

World Bank. (2012). Protecting poor and vulnerable household in Indonesia. Jakarta: World Bank Jakarta Office.

Zamroni. (2010). Pendidikan dan kemiskinan. In Tukiran, A.J. Pitoyo, \& P.M. Kutanegara (Eds.). Akses penduduk miskin terhadap kebutuban dasar [Access of poor inhabitants towards primary needs] (pp.185-221). Yogyakarta: Pusat Studi Kependudukan dan Kebijakan, Universitas Gadjah Mada. 